\title{
Endophytic microorganisms of tropical tuber crops: Potential and perspectives
}

\author{
Shubhransu Nayak ${ }^{1 *}$, Archana Mukherjee ${ }^{2}$ and Soma Samanta ${ }^{2}$ \\ ${ }^{1}$ Odisha Biodiversity Board, Regional Plant Resource Centre Campus, Bhubaneswar751015 (Odisha), INDIA \\ ${ }^{2}$ Crop Improvement Division, ICAR-Central Tuber Crops Research Institute-RC, Bhubaneswar-751015 (Odisha), INDIA \\ *Corresponding author. E-mail: shubhransu.cri@@gmail.com
}

Received: July 5, 2016; Revised received: January 28, 2017; Accepted: April 26, 2017

\begin{abstract}
Endophytic microorganisms which include both bacteria and fungi colonise almost every plant species. In order to colonize the plant and compete with other microorganisms, they produce a plethora of secondary metabolites, including toxins, enzymes, antibiotics, anti-cancer, anti-inflammatory and antifungal compounds. Endophytic fungi can have profound impacts on plant communities which include abiotic and biotic stress tolerance, increase of biomass, decrease of water consumption and alteration of resource allocation, nitrogen fixation, increased drought resistance, thermal protection, survival under osmotic stress and degradation of pollutants. Though tuber crops are the second most important group of crop plants providing food energy to humans after cereals, less attention has been paid to the these traditional crops in general. Investigations regarding the association of endophytes with the tuber crops have been sparsely studied though in some tuber crops like cassava, sweet potato and yams, presence of endophytes have been reported. Hence from the scarcely available literature, in the current review an attempt was made to put light on the various beneficial activities of endophytes on tuber crops. These reports glorified many symbiotically associated endophytes to have antagonistic properties against many plant pathogens like Rhizoctonia solani, Pythium aphanidermatum and Sclerotium rolfsii. Species like Rahnella was resilient to cold shock, UV irradiation and antibiotics. Many diazotropihic and non-diazotropihic endophytic bacteria were involved in nitrogen fixation. Actinomycetes endophytes were novel sources of industrially important thermostable amylolytic enzymes. However, inspite of all these profound beneficial effects endophytic associations are still to be studied in many tuber crops like taro, elephant foot yam, greater yam etc. So this review put forward the urge to carry out comprehensive research on these important microbes on such important crops.
\end{abstract}

Keywords: Cassava, Endophytes, Sweet potato, Tuber crops, Yam, Yam bean

\section{INTRODUCTION}

The term endophyte was first coined in 1886 by German Botanist and father of plant pathology Anton de Bary who described endophytes as microorganisms that colonize internal tissues of stems and leaves of plants. Infection caused by endophytes was further clarified to be asymptomatic i.e. without causing any apparent harm to the host (Hallmann et al., 1997). They can colonise roots as well as shoots and may not remain as endophyte throughout their life cycle (Wilson, 1995; Porras-Alfaro and Bayman, 2011). Endophytic microorganisms which include both bacteria and fungi colonise almost every plant species. Perhaps ninety species in a single tropical tree leaf and more than fifty different genera of endophytes are associated with roots of an arid grassland species (Porras-Alfaro and Bayman, 2011). In order to colonize the plant and compete with other microorganisms, they produce many enzymes, toxins and a plethora of secondary metabolites which includes enzymes, antibiotics, anticancer, anti-inflammatory and antifungal compounds (DeMelo et al., 2009). Fungal endophytes appear to be associated symbiotically with most, if not all, plants in natural ecosystem and constitute important components of plant micro-ecosystems. These fungal symbionts can have profound effects on plant ecology, fitness, and evolution, shaping plant communities and manifesting strong effects on the community structure and diversity of associated organisms (e.g. bacteria, nematodes and insects). Endophytic fungi can have profound impacts on plant communities. They may increase fitness by conferring abiotic and biotic stress tolerance, increasing biomass and decreasing water consumption, or may decrease fitness by altering resource allocation (Rodriguez et al., 2008). Fungal endophytes were also reported to produce 'gold' bioactive compound paclitaxel (taxol) and many other bioactive molecules like alkaloids, terpenoids, steroids, quinones, lignans, phenols and lactones (Zhao et al., 2010). Besides fungi, endophytic bacteria have been detected inside the endorhiza, in stems, leaves as well as inside plant reproductive organs of different host plants. However, they occur at lower population densities than rhizospheric bacteria or bacterial pathogens (Rosenblueth and Martinez-Romero, 2006). Several bacterial endophytes provide phytohormones, low 
molecular weight compounds, enzymes, antimicrobial substances and side rophores which supported plant growth and increased nutrient uptake. Some endophytes have been identified as ideal candidates for biological control those could offer increased resistance to pathogens. Endophytes are also found to help plants in nitrogen fixation, increased drought resistance, thermal protection and survival under osmotic stress. In recent studies several pollutants has also been found to be degraded by this group of microbes (Khan and Doty, 2009; Dotty, 2008). The most commonly isolated genera include Bacillus, Burkholderia, Enterobacter, Erwinia, Pseudomonas and Xanthomonas (Hallmann et al., 1997; Teixeira et al., 2007). Endophytes are indirectly associated with the induction of secondary metabolites production by plants as observed in aromatic and medicinal plants. Some metabolites are produced by a plant in combination with associated endophytic bacteria where the plant is unable to produce them alone (Brader et al., 2014). Similarly many novel compounds and antifungal metabolites synthesised de novo mediated by bacterial endophytes endophytes have been shown to prevent disease development in plants (Ryan et al., 2008). Endophytic microorganisms have frequently been reported to be associated with crop plants, including wheat (Triticum aestivum), wild barley (Hordeum brevisubulatum and Hordeum bogdanii), soya bean (Glycine max), and maize (Zea mays). Some of the endophytic fungi in these crops conferred resistance of the plant to insect or fungal pathogens (Yuan et al., 2010). However, the frequent occurrence of endophytic microbes in many other important agricultural crops such as tuber crops and subsequent relevance to crop production systems is yet to be explored widely (Loeffler et al., 1986; Krebs et al., 1998; DeMelo et al., 2009).

Roots and tubers are some of the most important consumed crops and have a major place in our diet and include extremely important crops worldwide. These crops contribute significantly to income generation, sustainable development and household food security especially in low income countries which are mainly located in the tropical regions. Tuber crops are the second most important group of crop plants which provide $5.4 \%$ of food energy to humans towards global food security after cereals which provide $49 \%$ (Nayar, 2014; FAO, 2009). More importantly, tropical root and tuber crops which include cassava, sweet potato, yams and aroids, are essential as staple foods and are utmost important for world food security. These are major sources of energy in developing countries with fast population growth and high urbanisation rates. With a contribution of $3.9 \%$ of human energy and an average consumption of $28.6 \mathrm{~kg}$ per capita per year (76 kcals capita-1 day-1) tropical tuber crops (TTCs) like cassava, sweet potato and yam stand among the top 15 crop plants of the world when cultivation area is concerned (Lebot, 2009; Nayar, 2014). Other tuber crops include elephant foot yam, yam bean and edible aroids like taro. Despite such importance, less attention have been paid to these traditional crops towards their improved production and association with microorganisms. Though the presence of endophytes has been explored in some of these crops, sufficient information is lagging regarding the importance and utilisation of these important microbes in these important crops. In the current review, isolation of a wide range of bacterial as well as fungal endophytes and subsequently their bioactive potential has been discussed. The aim of the review is to put forward the need of intensified research in this direction.

Endophytes of cassava: Cassava (Manihot esculenta Crantz ssp. esculenta) is a perennial woody shrub in the Euphorbiaceae (spurge) family native to South America but now grown in tropical and subtropical areas worldwide, for the edible starchy roots (tubers), which are an major food source in the developing world, including Africa, South America and Oceania. Many ethno varieties are being cultivated by Brazilian Amazon Indian tribes. Cassava roots contain about $25-$ $35 \%$ starch and serve as a primary staple food over 800 million people of the world majority of them belongs to poorest population of humid tropical countries (Lebot, 2009; Chipeta and Bokosi, 2013). Cassava is yet to receive major attention in crop research programs despite being a globally important as a subsistence crop (DeMelo et al., 2009). The existence of endophytes in cassava was suspected long before due to the following reasons: (a) Plants having no symptoms of disease growing in the same field frequently showed a wide range of variation in root yield.(b) Root yield of low-yielding, virus free plants of traditional clones could be increased by meristem culture (c) the performance (i.e., Root yield) of meristem culture-derived plants decreased sharply and uniformly under field conditions and (d) the long growing cycle of cassava and its vegetative propagation allowed infection and dissemination of these parasites. Because of these, several fungal species have been isolated from symptomless plant parts of cassava. The fungal species included Septoria nodurum, Fusarium oxysporum, Colletotrichum gloeosporioides, C. graminicola, Alternaria termissima, Trichoderma sp., Botrytis sp., Torula sp., Nigrospora sp., and others (Rivera et al. 1993; CIAT, 1992).

Both detrimental and beneficial effects of endophytes have been observed in plants and in the case of cassava it depended on the method of inoculation. For example Curvularia $s p$. was found to be detrimental when spray -inoculated, but beneficial when inoculated by immersion or puncturing on plantlets and callus tissues of cassava variety $\mathrm{M} \mathrm{Col} 2215$. This phenomenon may be due to the pathogenic nature of some strains of 
Curvularia towards many plants. Some endophytes e.g. Rhizoctonia behaved as endophyte in a particular tissue (leaf and stem) but it induced necrosis in roots. Varietal interactions were also observed to vary for endophytic activity in case of cassava (Rivera et al., 1993; CIAT, 1992). Several bacterial endophytes having multiple bioactivities were also found to be associated symbiotically with cassava plant. In many cases these bacteria were with profound antagonistic effect against many devastating plant pathogens. Many cassava cultivars were found to have a strong association with bacterial endophyte Hyphomicrobium. The bacteria appeared on culture media when explants carrying an axillary bud of cassava cultivar TME204 from the greenhouse and field, was introduced for ebryogenesis (Chauhan et al., 2013).

DeMelo et al. (2009) isolated sixty seven endophytic bacteria from freshly collected healthy roots, stems and leaves of six cassava varieties grown by Indian tribes located in the Autazes region, Amazonas State of Brazil. About $25 \%$ of the cultures belonged to Bacillus species of which bacterial strain Bacillus pumilus MAIIIM4A produced an antifungal compound pumilacidin, hence exhibited strong antagonistic activity against plant pathogenic fungi like Rhizoctonia solani, Pythium aphanidermatum and Sclerotium rolfsii. Other antagonistic bacteria such as Enterobacter cancerogenus MAIVM2a, Bacillus anthracis MAIVM3a, B. anthracis MAIIIM2b, Kluyvera cryocrescens MAIIR2b, Bradyrhizobium japonicum MAIIIR3a, B. pumilus MAIIIM4a, B. cereus MAIF4b, Clavibacter michiganensis isidiosum MAIF6b, B. cereus MAIVM1b and Burkholderia cepacia were also isolated along with Bacillus pumilus MAIIIM4A. Similarly, twenty endophytic bacteria were isolated from surface sterilised cassava stems of which Pseudomonas species exhibited in vitro bacteriostatic activity against cassava bacterial blight pathogen Xanthomonas campestris $p v$. manihotis. The size of inhibiting or clear zone was more than $30 \mathrm{~mm}$ (Purnawati and Nirwanto, 2013). Teixeira et al. (2007) isolated 482 endophytic microorganisms from cassava land races and commercial areas in three Brazilian states such as Sao Paulo, Amazonas and Bahia. After cultural and morphological groupings" of endophytes from all three states, 47 different species belonging to 27 genera were identified and the most frequently isolated were Bacillus, Burkholderia, Enterobacter, Escherichia, Salmonella, Stenotrophomonas and Serratia. These genera represented approximately $71 \%$ of isolates identified. Among bacterial isolates $60 \%$ belonged to the group $B$. cereus (including the species B. cereus, B. anthracis , B. mycoides, and $B$. thuringiensis), $16.3 \%$ of the species were $B$. pumilus and $9 \%$ of the species were $B$. megaterium. The other $18.4 \%$ belonged to species such as B. lentimorbus, B. subtilis, B. sphaericus and $B$. Atrophaeus. Other cassava endophytic bacteria like
Paenibacillus sp. IIRAC-30 which was isolated from cassava suppressed the plant pathogen Rhizoctonia solani. In addition to that Paenibacillus sp. IIRAC-30 also produced ethyl acetate in potato dextrose medium which indicated presence of C15- lipopeptide belonging to surfactin series (Canova et al., 2010; Menpara and Chanda, 2013).

Endophytes of sweet potato: Sweet potato (Ipomoea batatas (L.) Lam) is the second most important root tuber and the seventh most important food crop of the world, an important root crop grown for its sweet testing starchy, tuberous roots (Mitra, 2012). This carbohydrate rich root crop is used as subsidiary food, the vine tips used as vegetables and vines along with leaves serves as fodder. Among the world's major food crops, sweet potato produces the highest amount of edible energy per hectare per day (Horton and Fano, 1985). It has also shown potential to tolerate and absorb heavy metal pollutants like lead, iron and cadmium, as well as mixed pollutants contained in landfill leachate (DeAraujo et al., 2004).

Growth and stress tolerance inducing endophytes: Several bacterial endophytes from sweet potato have been isolated, identified and their biological significance in crop production, protection and improvement has been emphasised. The population levels of endophytic bacteria ranged from $10^{2}$ to $10^{4} \mathrm{~g}^{-1}$ fresh weight of surface sterilised stem of sweet potato (Adachi et al., 2002). Eleven culturable bacterial endophyte strains belonging to the genera, Enterobacter, Rahnella, Rhodanobacter, Pseudomonas, Stenotrophomonas, Xanthomonas and Phyllobacterium, have been isolated from sweet potato stems. Among these endophytes Pseudomonas, Rahnella and Enterobacter produced higher amount of Indole acetic acid (IAA) which proved to have plant growth promoting effect. Rahnella $s p$. also resilient to stresses like cold shock, UV irradiation and antibiotics (Khan and Doty, 2009). Plant growth promoting (PGP) activity was also observed in case of fungal endophytes of sweet potato. Thirty out of thirty six fungal endophytes, isolated from six healthy looking leaves, stems and roots of sweet potato from Baguio City of Philippines exhibited plant growth promoting effect on rice. Two such isolates viz. Fusarium oxysporum Isolate UOA/HCPF and Emericella nidulans Strain FH5 produced secondary metabolites having significant PGP effect which increased significantly rice plant length for the seedlings treated with the culture filtrates without causing external manifestations of infection (Hipol, 2012).

Diazotrophic and non-diazotrophic endophytic bacteria: The diazotrophic nature of some bacterial endophytes also has been verified by growth in nitrogen free media and the presence of nifH sequences has been detected. Many Japanese sweet potato cultivars were found to be associated with diazotrophic endophytic bacteria. Four diazotrophic Pantoea spp. and 
five Klebsiella spp along with three non-diazotropihic Enterobacter spp. have been isolated from Japanese sweet potato stems by stem pieceincubation and acetylene reduction activity (SPI-ARA) method using a semi-solid (1.8 grams agar/L) modified Rennie (MR) medium (Elbeltagy et al., 2001; Rennie, 1991). The acetylene reduction activity of diazotrophic strain $P$. agglomerans was found to be increased when cocultured with non-diazotrophic strain E. asburiae (Asis jr and Adachi, 2005). Another endophytic diazotroph Klebsiela oxytoca was isolated from Japanese sweet potato cultivar Beniotome (Adachi et al., 2002). Potential nitrogen fixing endophytes were isolated from sweet potato varieties collected in Uganda and Kenya. The nifH gene sequences had high homologies to the nitrogenise reductases of known nitrogen fixing bacteria (Reiter et al., 2003). The occurrence of these endophytic nitrogen fixers apparently supports the findings of Yoneyama et al. (1998) on the possible contribution of biological nitrogen fixation in sweet potato.

Endophytes associated with Dioscorea species: Plants under the genus Dioscorea are commonly known as yam, tuber crop belonging to the family Dioscoreaceae which are mainly cultivated for the consumption of their starchy tubers in Africa, Asia, Latin America, the Caribbean and Oceania. Yams are among the oldest food crops recorded and are defined as an economically useful plant belongs to the botanical genus Dioscorea. Speciesof Dioscorea are also important source of sapogenins, alkaloids, steroid derivatives and phenolic compounds which are used in the pharmaceutical industry and diosgenin, which is used in the manufacture of oral contraceptives and sex hormones (Maggirwar et al., 2013; Ravi et al., 1996). Association of microbial endophytes with Dioscorea species has been reported mainly in yam crop where a poor diversity of endophytes was observed. Bacterial strains belonging to Erwinia and Bacillus species e.g. Erwinia pyrifoliae and Erwinia-Pantoea complex have been isolated from yam rhizomes or tubers. Zhang et al. (2010) and Omoregie et al. (1999) isolated 14 and 10 numbers of endophytes from various yam tubers in two separate studies, respectively. In some cases cooccurrence of Dark Septate Endophyte (DSE) and Arbuscular Mycorrhizae Fungi (AMF) which are good symbionts have also been observed in Yam (Maggirwar et al. 2013). However, this endophytic colonisation is being a constraint in commercial propagation of yams by tissue culture technique and eventually difficulties arise to be used these in formal seed system. To eliminate such endophytic bacteria like Burkholderia spp., Bacilluscereus and Luteibacter rhizovicinus antibiotics like rifampicin are being used. Similarly, endophytic fungi like Cladosporium sp, Verticillium sp and Amerosporium sp are eliminated by a fungicide mixture of lambda-cyhalothrin andmancozeb/carbendazim (IITA; Wakil and Mbah et al.,
2012).

Endophytes of yam bean: Yam bean (Pachyrhizus erosus L. Urban) is a tuber legume, native to Central Mexico and the Northern Amazon Region. Its tubers are used as a source of starch for various applications, particularly in the food industry (Stamford et al., 2007). Till date some actinomycetes were reported to occur endophytically with yam bean tubers. These actinomycetes were found to be novel sources of industrially important thermostable amylolytic enzymes. Thermo stability upto $70{ }^{0} \mathrm{C}$ of $\alpha$-amylase enzyme from actinomycete Nocardiopsis sp isolated from yam bean was observed. The $\alpha$-amylase was effective in a wide range of $\mathrm{pH}$ and was having high residual activity (Stamford et al., 2001). Similarly another endophytic actinomycete isolated from tubers of yam beam was classified as a novel species and nominated as Kitasatospora recifensis based in phenotypic and genotypic analysis. This strain produced simultaneously two amylases

( $\alpha$-amylase and amyloglucosidase) that showed thermostable properties. These desirable enzyme characteristics indicate that this strain has great potential for use in agricultural and biotechnological applications for starch hydrolyzation (Stamford et al., 2007).

Tuber crops from which endophytes still to be reported: Despite the above explorations, many important tuber crops are still to be looked for endophytic associations. Reports regarding such mutualism is lacking in the database. However, in a recent study by Nayak et al. (2016), endophytic colonisation in tuber crops like taro, greater yam and elephant foot yam was explored. Taro [Colocasia esculenta (L.) Schott] is a root crop cultivated mainly for the edible corms. It is grown in nearly all parts of the humid tropics in more than 65 countries worldwide and serves as an important staple food and as a source of carbohydrate for inhabitants in some subtropical and virtually all tropical regions (Tsedalu et al., 2014). Taro is known to be a good source of carbohydrate, fibre, minerals especially potassium and vitamins (vitamin $\mathrm{A}, \mathrm{C}$ and $\mathrm{B}$ complex) which is more than that found in whole milk. Considering this importance, an International Network for Edible Aroids (INEA) has been started in April, 2011 involving 22 countries. Central Tuber Crops Research Institute Regional Centre (CTCRI RC), Bhubaneswar, India is one of the experimental stations. Three putative fungal endophytes have been isolated from leaf cuttings of three INEA taro lines viz. BL/SM/158, $\mathrm{BL} / \mathrm{SM} / 132$ and $\mathrm{CE} / \mathrm{IND} / 10$ which are being identified and evaluated at CTCRI RC along with two isolates from greater yam genotype BBSR-1 and one isolate from elephant foot yam genotype NDA-4. Studies regarding isolation, identification and utility of endophytes from other lines and varieties are being carried out at this centre along with studies for the establishment of mutualistic relationship of endophytes with 
these crops.

\section{Conclusion}

The potential of endophytic microorganism for a sustainable agricultural production is enormous. Though breeding programmes and cultivar genotyping solve many problems in agriculture, trapping of these ecologically important microbes may also complement such efforts. Beneficial endophytic fungi and bacteria can be used as inoculant in roots and other plant tissues for many tuber crop plants to enjoy the benefits of these mutualists which they confer to their original plant hosts. Many growth promoting endophytes may be applied as potential bio-fertilizers in tuber crops with minimal environmental risks. The non-pathogenic existence of endophytes in their host (like yam bean) and their genetic element could be explored for possible exploitation as vectors in the genetic engineering. Investigation of biodiversity of endophytes may explore new possibilities for biological control for many plant diseases. However, the colonization and establishment pathway of endophytes into the plants as well as the extent and mechanism of the contribution of the biologically fixed Nitrogen by the diazotrophic endophytes to the host plant remain to be studied. Hence, a consolidated effort is required to further intensify studies regarding isolation and utilisation of more numbers of endophytic microbes from tuber crops.

\section{ACKNOWLEDGEMENTS}

The authors are thankful to Dr. S.K. Chakrabarti, Former Director, ICAR-CTCRI, Bhubneshwer for his constant guidance and the infrastructure facilities for the study. Financial supports of Protection of Plant Varieties \& Farmers' Rights Authority (PPV\&FRA), Govt. of India, New Delhi and EU aided International Network for Edible Aroids (INEA), Coordinated through SPC, Fiji are sincerely acknowledged.

\section{REFERENCES}

Adachi, K., Nakatani, M. and Mochida, H. (2002). Isolation of an endophytic diazotroph, Klebsiella oxytoca, from sweet potato stems in Japan. Soil. Sci. Plant Nutr., 48 (6): 889-895

Asis Jr, C. A. and Adachi, K. (2005). Endophytic bacteria associated with sweet potato \& their interaction under co-culture conditions. Phil. J Crop Sci., 30(1): 37-45

Brader, G., Compant, S., Mitter, B., Trognitz, F. and Sessitsch, A. (2014). Metabolic potential of endophytic bacteria. Curr. Opin. Biotech., 27: 30-37

Canova, S. P., Petta, T., Reyes, L. F., Zucchi, T. D., Moraes, L. A. B. and Melo, I. S. (2010). Characterization of lipopeptides from Paenibacillus sp. (IIRAC30) suppressing Rhizoctonia solani. World. J. Micro. Biot., 26: 2241-2247

Centro Internacional de Agricultura Tropical (1992). Working Document No. 116, Cassava Program 1987-1991, Released October, 1992. Retrived on $10^{\text {th }}$ December
2016 from http://pdf.usaid.gov/pdf_docs/ PNABN419.pdf.

Chauhan, R. D., Beyene, G. and Taylor, N. J. (2013). Identification of Hyphomicrobium as a bacterial endophyte of cassava (Manihot Esculenta Crantz) and its elimination from In Vitro cultures. In vitro biology meeting. 2013 meeting of the society for in vitro biology. June 15-19, Providence, Rhode Island. Retrived on $10^{\text {th }}$ December 2016 from https://sivb.org/meetings/ pastmeetings/2013Meeting/2013Assets/addendum $\%$ 20booklet.pdf.

Chipeta, M. M., Bokosi, J. M. (2013). Status of Cassava (Manihot esculenta) Production and utilization in Malawi. International. J. Agron. Plant. Product, 4 (S): $3637-$ 3644

De Melo, F. M. P., Fiore, M. F., DeMoraes, L. A. B., Stenico, M. E. S., Scramin, S., Teixeira, M. A. and DeMelo, I. S. (2009). Antifungal Compound Produced by the Cassava Endophyte Bacillus pumilus MAIIIM4A. Sci. Agric. (Piracicaba, Braz.), 66(5): 583592

DeAraujo, B. S., de Oliveira, J. O., Machado, S. S. (2004). Comparative studies of the peroxidases from hairy roots of Daucus carota, Ipomoea batatas and Solanum aviculare. Plant. Sci., 167: 1151-1157

Doty, S. L. (2008) Enhancing phytoremediation through the use of transgenics and endophytes. New. Phytol., 179:318-333

Elbeltagy, A., Nishioka K., Sato T., Suzuki H., Ye B., Hamada T., Isawa T., Mitsui H., and Minamisawa K. (2001). Endophytic colonization and in planta nitrogen fixation by a Herbaspirillum sp. isolated from wild rice species. Appl. Environ. Microbiol., 67: 5285-5293

FAO. Food and Agriculture Organization (2009). How to Feed the World in 2050 A.D. Executive Summary., Rome. Retrived on $10^{\text {th }}$ December 2016 from http:// www.fao.org/fileadmin/templates/wsfs/docs/ expert_paper/How_to_Feed_the_World_in_2050.pdf.

Hallmann, J., Quadt-hallmann, A., Mahaffee, W. F. and Kloepper, J. W. (1997). Bacterial endophytes in agricultural crops. Canadian. J. Microbiol., 43: 895-914

Hipol, R. M. (2012). Molecular Identification and Phylogenetic Affinity of Two Growth Promoting Fungal Endophytes of Sweet Potato (Ipomea batatas (L.) Lam.) from Baguio City, Philippines. Elect. J. Biol., 8(3): 5761

Horton, D. and Fano, H. (1985). Potato Atlas, International Potato Center (CIP), Lima, Peru. p. 136.

IITA: International Institute of Tropical Agriculture, PMB. 5320 , Oyo Road Ibadan, Nigeria. Retrived on $10^{\text {th }} \mathrm{De}-$ cember $2016 \quad$ fromhttp://www.iita.org/c/ document library/get file? p_1_id $=45268 \&$ folderId $=7172121 \&$ name $=$ DLFE8906.pdf.

Khan, Z. and Doty, S. L. (2009). Characterization of bacterial endophytes of sweet potato plants. Plant. Soil. 322 (1): 197-207.

Krebs, B., Höding, B., Kübart, S., Alemayehu-Workie, M., Junge, H., Schmiedeknecht, G., Grosch, R., Bochow, H. and Hevesi, M. (1998) Use of Bacillus subtilis as biological control agent. I. Activities and characterization of Bacillus subtilis strains. J. Plant Dis. Prot., 105:181197

Lebot, V. (2009). Tropical Root and Tuber Crops: Cassava, 
Sweet Potato, Yams and Aroids; CAB International: Oxford, UK, 2009; Crop Production Science in Horticulture Series, 17, P. 413

Loeffler, W., Tschen, S. M., Vanittanakom, N., Kugler, M., Knorpp, E., Hsieh, T. F., Wu, T. G. (1986) Antifungal effects of bacilysin and fengymycin from Bacillus subtilis F29-3: a comparison with activities of other Bacillus antibiotics. J. Phytopath., 115: 204-213

Maggirwar, R. C., Tayde, S. S., Khodke, S. P., Deotare, P. W. and Hedawoo, G. B. (2013). Incidence of Arbuscular Mycorrhizal and Dark Septate Fungal association in Dioscorea species, Int. J. Life. Sci., 1(3): 161-164

Menpara, D. and Chanda, S. (2013). Endophytic bacteriaUnexplored reservoir of antimicrobials for combating microbial pathogens. In: Mendez-Vilas A (Ed) Microbial Pathogens and Strategies for Combating them: Science, Technology and Education. Formatex, Badazoj, Spain, 1095-1103

Mitra, S. (2012). Nutritional Status of Orange-Fleshed Sweet Potatoes in Alleviating Vitamin A Malnutrition through a Food-Based Approach. J. Nutr. Food. Sci., 2(8): 160

Nayak, S., Mukherjee, A., Kishore, K., Mandal, S., Pillai, R and Patro, R. (2016). Putative endophytic fungi from taro (Colocasia Esculenta), greater yam (Dioscorea Alata) and elephant foot yam (Amorphophallus Paeoniifolius). Int. J. Agr. Env. Biotech., 9(2): 209-212

Nayar, N. M. (2014). The Contribution of Tropical Tuber Crops Towards Food Security. J. Root. Crops, 40 (1): 1 $-12$

Omoregie, S. N., Asemota, H. N., Osagie, A. U., Mantell, S. and Ahmad, M. H. (1999). Occurrence of free-living bacteria in tubers of Dioscorea yams. Trop. Agri., 76 (4): $250-255$

Porras-Alfaro, A. and Bayman, P. (2011). Hidden Fungi, Emergent Properties: Endophytes and Microbiomes. Annu. Rev. Phytopathol, 49: 291-315

Purnawati, A. and Nirwanto, H. (2013). Endophytic Bacteria as Biocontrol Agents of Xanthomonas campestris pv. manihotis on Cassava In Vitro. 4th International Conference on Global Resource Conservation \& 10th Indonesian Society for Plant Taxonomy Congress Brawijaya University, February 7-8th, 2013.

Ravi, V., Aked, J. and Balagopalan, C. (1996). Review on tropical root and tuber crops, Storage methods and quality changes. Crit. Rev. Food Sci. Nutr., 36: 661-709

Reiter, B., Burgmann, H., Burg, K. and Sessitsch, A. (2003). Endophytic nifH gene diversity in African sweet potato. Canadian. J. Microbial., 49(9): 549-555

Rennie, R. J. (1981). A single medium for the isolation of acetylene-reducing (dinitrogen-fixing) bacteria from soils. Can. J. Microbiol., 27: 8-14

Rivera, M. F., Laberry, R. and Lozano, J. C. (1992). Evidences for Endophytes Parasiting Traditional Clones of Cassava (Manihot esculenta crantz). Proceedings of the first international scientific meeting cassava biotechnology network. Organized by the Biotechnology Research Unit, Cassava Program, and Institutional Development
Support Program, Centro Internacional de Agricultura Tropical (CIAT) Cartagena de Indias, Colombia 25-28 August 1992.

Rodriguez, R. J., White, J. F. Jr., Arnold, A. E. and Redman, R. S. (2009). Fungal endophytes: diversity and functional roles. New Phytologist.

Rosenblueth, M. and Martinez-Romero, E. (2006). Bacterial Endophytes and Their Interactions with Hosts. Mol. Plant-Microbe. Interact., 19 (8): 827-837

Ryan, R. P., Germaine, K., Franks, A., Ryan, D. J. and Dowling, D. N. (2008). Bacterial endophytes: recent developments and applications. FEMS Microbiol. Lett., 278: $1-9$

Stamford, T. L. M., Stamford, N. P., Coelho, L. C. B. B. and Araujo, J. M. (2001) Production and characterization of a thermostable $\alpha$-amylase from Nocardiopsis sp. endophyte of yam bean. Biores Technol., 76(2), 137-141

Stamford, T. L. M., Stamford, T. C. M., Stamford, N. P., Santos, C. E. R. S., Ha-Park, Y., Bae, J. W. and Araujo, J. M. (2007). Interspecies variation of Kitasatospora recifensis endophytic from yam bean producing thermostable amylases in alternative media. World J Microbiol Biotechnol., 23(12): 1719-1724

Teixeira, M.A., DeMelo, I.S., Vieira, R.F., Costa, F.E.C. and Harakava, R. (2007). Cassava endophytic microorganisms of commercial plantings and ethnovarieties in three Brazilian states. Pesq. Agropec. Bras., 42 (1)

Tsedalu, M., Tesfaye, B. and Goa, Y. (2014). Effect of type of planting material and population density on corm yield and yield components of taro (Colocasia esculenta 1.). J. Biol. Agri. Healthcare, 4(17): 124-137

Wakil, S. M. and Mbah, E. I. (2012). Screening Antibiotics for the Elimination of Bacteria from in vitro Yam Plantlets. AU J Technol., 16(1): 7-18

Wilson, D. (1995) Endophyte-The evolution of a term, and clarification of its use and definition. Olkos, 73: 274-276

Yoneyama, T., Terakado, J. and Masuda, T. (1998). Natural abundance of $15 \mathrm{~N}$ in sweet potato, pumpkin, sorghum and castor bean: Possible input of Nc-derived nitrogen in sweet potato. Bioi. Ferti. Soil., 26: 152-154

Yuan, Z., Zhang, C., Lin, F. and Kubicek, C. P. (2010). Identity, Diversity, and Molecular Phylogeny of the Endophytic Mycobiota in the Roots of Rare Wild Rice (Oryza granulate) from a Nature Reserve in Yunnan, China. Appl. Env. Microbiol., 76 (5): 642-1652

Zhang, Z. D., Xie, Y. Q., Chu, M., Gu, M. Y., Song, S. Q., Tang, Q. Y. and Mao, J. (2010). Study on Isolation and Identification of Endophytes in Yam Rhizome [J]. Xinjiang. Agri. Sci., 1: 024

Zhao, J., Zhou, L., Wang, J., Shan, T., Zhong, L., Liu, X. and Gao, X. (2010). Endophytic fungi for producing bioactive compounds originally from their host plants. Current Research, Technology and education topics in Applied Microbiology and Microbial Biotechnology, Formatex, Spain, pp 567-576 